\title{
Pengembangan Bahan Ajar IPA Berbasis Lingkungan Di Sekolah Dasar Negeri 3 Jenggik Tahun Pelajaran 2017/2018
}

\author{
${ }^{1}$ Sandy Ermanda ${ }^{2}$ Nunung Ariandani \\ Institut Agama Islam Hamzanwadi NW Pancor \\ sandy.ermanda88@gmail.com
}

\begin{abstract}
Abstrak
Penelitian ini bertujuan untuk mengetahui langkah-langkah pengembangan bahan ajar IPA berbasis lingkungan, untuk mengetahui hasil pengembangan bahan ajar IPA berbasis lingkungan dan untuk mengetahui pengaruh penggunaan bahan ajar berbasis lingkungan terhadap hasil belajar Ilmu Pengetahuan Alam siswa kelas IV Sekolah Dasar.

Penelitian ini merupakan penelitian pengembangan dengan mengadopsi model pengembangan Borg and Gall yang terdiri dari 7 tahapan yang disederhanakan yaitu analisis kebutuhan, desain, pembuatan prototype bahan ajar, uji coba bahan ajar, revisi bahan ajar, penerapan bahan ajar dan revisi terakhir.penelitian pengembangan ini menggunakan desain uji coba one group pretes-posttes desaign. Subjek penelitian adalah siswa kelas IV SDN 3 Jenggik sebanyak 23 siswa yang terdiri dari 10 orang siswa laki-laki dan 13 orang siswa perempuan. Data yang diperoleh dalam penelitian ini adalah data kualitatif dan kuantitatif.Instrument pengumpulan data meliputi tes dan angket respon siswa.Teknik analisis data yang digunakan dalam penelitian ini adalah skala empat untuk validasi bahan ajar dan thitung untuk mengetahui pengaruh bahan ajar terhadap hasil belajar siswa.

Hasil penelitian menunjukkan suatu peningkatan hasil posstes siswa meningkat dibandingkan hasil pretes yaitu sebelum menggunakan bahan ajar IPA berbasis lingkungan dalam pembelajaran. Berdasarkan hasil posttes siswa pada uji coba lapanganyang dilaksanakan di SDN 3 Jenggik diperoleh rata-rata nilai siswa 75,21 , dengan ketuntasan klasikal 82,6\%. Sedangkan hasil pretes siswa diperoleh nilai rata-rata 61,52 ,dengan ketuntasan klasikal $43,47 \%$. Sementara respon siswa terhadap bahan ajar IPA berbasis lingkungan dikategorikan tinggi yaitu dengan rata-rata 83,12 yang berada pada rentang skor 85,27 $>\mathrm{X} \geq 83,12$. Pengaruh bahan ajar IPA berbasis lingkungan terhadap hasil belajar IPA siswa dianalisis menggunakan $t_{h i t u n g}$.Diperoleh hasil thitung 12,015 , kemudian dibandingkan dengan hasil $t_{\text {tabel }}$ dengan taraf signifikan 5\%, yaitu 12,015 berbanding 1,721.Berdasarkan hasil perbandingan nilai $t_{\text {hitung }}$ dengan $t_{\text {tabel }}$ pada skala kecil dan besar, diperoleh nilai thitung lebih besar dari $t_{\text {tabel, }}$ maka bahan ajar IPA berbasis lingkungan sebagai produk hasil pengembangan dikatakan berpengaruh terhadap hasil belajar IPA siswa.
\end{abstract}

Kata kunci: Pengembangan, Bahan Ajar IPA Berbasis Lingkungan 


\section{PENDAHULUAN}

Berdasarkan hasil observasi di lapangan tepatnya di SDN 3 Jenggik dalam proses pembelajaran pada mata pelajaran IPA pada materi bagian-bagian tumbuhan dan fungsinya menunjukkan bahwa: (1) sebagian besar pembelajaran yang dilakukan belum menerapkan konsep yang berbasis lingkungan guru hanya mengajar di dalam kelas (2) pemanfaatan lingkungan untuk meningkatkan hasil belajar siswa masih dianggap sebagai pembelajaran yang jarang dilakukan oleh seorang guru (3) kendala mengenai keterbatasan waktu yang dipergunakan di kelas IV, merupakan kendala umum yang ditemui guru dalam menyampaikan materi serta guru kesulitan dalam mengkondisikan siswa dalam pembelajaran yang dilakukan di luar kelas.

Dalam proses pembelajaran ada beberapa masalah penting yang seringkali dihadapi guru dalam kegiatan pembelajaran terkait tentang bahan ajar, yaitu guru kurang dapat memilih dan menentukan materi pembelajaran atau bahan ajar yang tepat dalam rangka membantu siswa mencapai kompetensi. Hal ini disebabkan oleh kenyataan bahwa dalam kurikulum atau silabus, materi bahan ajar hanya dituliskan secara garis besar dalam bentuk "materi pokok".Tugas guru untuk menjabarkan materi pokok tersebut sehingga menjadi bahan ajar yang lengkap.Disinilah guru kurang dapat menentukan bahan ajar yang tepat yang sesuai dengan karakteristik siswa.Kebanyakan guru menggunakan bahan ajar yang sudah disiapkan oleh departemen pendidikan nasional yang disusun secara umum untuk digunakan secara umum juga di seluruh Indonesia. ${ }^{1}$

Masalah berikutnya yang sering dihadapi guru adalah guru memberikan bahan ajar atau materi pembelajaran terlalu luas dan melebar, terlalu mendalam, urutan penyajian yang tidak sistematis, dan jenis materi bahan ajar yang tidak sesuai dengan kompetensi yang ingin dicapai oleh siswa. Selain itu, yang menjadi masalah lain adalah bagaimana cara memanfaatkan bahan ajar. Pemanfaatan dimaksud adalah bagaimana cara mengajarkannya ditinjau dari pihak guru, dan cara mempelajarinya ditinjau dari pihak siswa serta kurang melibatkan lingkungan

\footnotetext{
${ }^{1}$ Hamzah B. uno, dan Mohamad, 2012. Belajar Dengan Pendekatan Pailkem.(Jakarta: Bumi Aksara.2012),hal,23
} 
sekitar siswa. Ketersediaan jumlah buku pelajaran juga dapat menjadi masalah yang dihadapi guru dalam proses pembelajaran, beberapa hal ini berpengaruh terhadap hasil belajar siswa.Diketahui nilai rata-rata ujian siswa semester I adalah 6,10. Ketuntasan Kompetensi Minimal (KKM) di sekolah tersebut untuk mata pelajaran IPA adalah 6,25. Dapat dikatakan bahwa nilai rata-rata siswa masih rendah.

Melihat keadaan tersebut, maka salah satu yang dapat digunakan untuk mengurangi masalah tersebut adalah dengan memilih bahan ajar yang dapat mencakup materi ajar yang kompleks namun tidak terlalu luas, intinya tujuan pembelajaran dapat dicapai sesuai dengan apa yang diharapkan, juga dapat mencakup urutan-urutan materi secara lengkap agar pengetahuan siswa juga dapat terstruktur baik dari hal-hal umum menuju khusus atau sebaliknya. Untuk memilih suatu bahan ajar yang kompleks, maka dapat disusun sebuah bahan ajar yang merupakan gabungan dari beberapa buku yang terkait.

Suatu proses pembelajaran akan lebih bermakna jika siswa sendiri yang aktif dalam mengkonstruksi pengetahuannya. Untuk mewujudkan keaktifan siswa dalam proses pembelajaran sangat diperlukan adanya bahan ajar yang berisi materi-materi yang disesuaikan dengan lingkungan sekitar siswa. Salah satunya adalah bahan ajar yang berbasis lingkungan.Bahan ajar IPA berbasis lingkungan merupakan bahan ajar yang di dalamnya membahas beberapa bidang kajian yang dipadukan karena masih memiliki keterkaitan dan dipadukan dengan lingkungan sekitar siswa. Sumber belajar utama yang dapat digunakan dalam pembelajaran IPA dapat berbentuk teks tertulis seperti buku, informasi lepas, atau berupa lingkungan sekitar seperti: lingkungan alam, lingkungan sosial dalam kehidupan sehari-hari, tetapi yang peneliti tekankan adalah lingkungan alam sekitar siswa yang mudah ditemukan dan diamati langsung oleh siswa. ${ }^{2}$

Pembelajaran berdasarkan lingkungan akan membantu anak didik untuk menyesuaikan dirinya dengan keadaan lingkungan sekitarnya. Pembelajaran IPA berbasis lingkungan atau pembelajaran dengan menggunakan bahan ajar berbasis

${ }^{2}$ Ahmadi, dan Amri, Konstruksi Pengembangan Pembelajaran Pengaruhnya Terhadap Mekanisme dan Praktik Kurikulum. (Jakarta: PT. Prestasi Pustakaraya.2010),hal,43 
lingkungan akan memotivasi peserta didik yang akhirnya dapat meningkatkan hasil belajar peserta didik, akan meningkatkan kerjasama antara guru, siswa dan lingkungan sehingga belajar akan menjadi lebih menyenangkan.

Berdasarkan uraian masalah di atas maka peneliti tertarik untuk melakukan penelitian dengan judul "Pengembangan Bahan Ajar IPA Berbasis Lingkungan di SDN 3 Jenggik".

Tujuan penelitian ini adalahuntuk menghasilkan bahan ajar IPA berbasis lingkungan yang efektif untuk meningkatkan hasil belajar siswa kelas IV di SDN 3 Jenggik.

\section{METODE PENELITIAN}

Penelitian ini mengembangkan produk berupa bahan ajar IPA berbasis lingkungan untuk siswa kelas IV Sekolah Dasar. Agar produk yang akan dikembangkan sesuai dengan tujuan maka penelitian pengembangan ini mengadaptasi model pengembangan Borg and Gall. Model ini terdiri dari 10 (sepuluh) tahapan. Berdasarkan kebutuhan pengembangan yang peneliti lakukan maka tahapan ini disederhanakan menjadi 7 tahapan yaitu analisis kebutuhan, desain, pembuatan prototype, uji coba lapangan, revisi bahan ajar dan penerapan model yang dikembangkan serta revisi terakhir.

Prosedur Pengembangan

Penelitian ini menggunakan prosedur pengembangan dengan mengadopsi model pengembangan Borg and Gall $^{3}$ Berikut penjelasan dari skema langkahlangkah penelitian model pengembangan Borg and Gall.Dalam penelitian ini, peneliti merancang dan memodifikasi model pengembanagn tersebut ke dalam 7 tahap yaitu:

1. Analisis Kebutuhan

Sebelum melakukan penelitian, pada tahapan ini peneliti melakukan observasi baik di dalam maupun di luar kelas dan mewawancarai kepala sekolah. Masalah yang peneliti temukan yakni mengenai sebagian besar pembelajaran yang dilakukan belum menerapkan konsep yang berbasis

${ }^{3}$ Arifin, Penelitian Pendidikan Metode dan Paradigma Baru. (Bandung: PT. Remaja Rosdakarya.2011),hal,91 
lingkungan dan pemamfaatan lingkungan masih dianggap pembelajaran jarang dilakukan oleh guru serta keterbatasan waktu yang dipergunakan dalam pembelajaran. Selain itu, guru dalam pembelajaran kurang variatif dalam menggunakan bahan ajar. Guru hanya menggunakan bahan ajar yang sudah disediakan oleh sekolah yang sumbangkan oleh pemerintah, tanpa ada pengembangan pada bahan ajar tersebut.

2. Desain

Tahap desain ini merupakan tahap perancangan produk awal model pembelajaran yang disesuaikan dengan masalah yang ada.Rancangan awal dalam desain ini berupa bahan ajar IPA.

3. Pembuatan Prototype Bahan Ajar

Pada tahap ini mulai disusun bentuk perancangan bahan ajar yang dikembangkan. Perancangan Produk berupa buku bahan ajar IPA berbasis lingkungan seperti: menyiapkan instrument alat pengumpulan data seperti lembar observasi, pedoman wawancara, untuk mengumpulkan semua informasi selama penerapan bahan ajar. Proses penelitian pada tahap ini dilakukan dengan melakukan validasi rancangan bahan ajar oleh pakar yang ahli. Hasil validasi kemudian dikaji untuk memperbaiki rancangan bahan ajar sebelum diujicobakan.

\section{Uji Coba Lapangan}

Tahap selanjutnya adalah uji coba lapangan.Pada uji coba ini disarankan mengambil sampel pada kelas IV SDN 3 Jenggik dengan jumlah 23 siswa.

\section{Revisi Bahan Ajar}

Revisi produk dilakukan setelah produk tersebut diterapkan atau diujicobakan.Pada saat uji coba lapangan hasil kurang optimal atau belum tercapainya tujuan.

6. Penerapan Bahan Ajar dalam Proses Pembelajaran

Implementasi bahan ajar dilakukan setelah pengujian dan revisi dua kali, Data yang diperoleh pada tahap ini kemudian dianalisis dan dilaporkan secara keseluruhan 


\section{Revisi Terakhir}

Sebelum bahan ajar dipublikasikan kesasaran pengguna yang lebih luas, tim ahli terakhir untuk memperbaiki hal-hal yang masih kurang baik hasilnya pada saat implementasi bahan ajar. Dengan adanya revisi terakhir ini, bahan ajar sudah benar-benar terbebas dari kekurangan dan layak digunakan pada kondisi yang sesuai dengan persyaratan penggunaan bahan ajar.

\section{HASIL PENELITIAN DAN PEMBAHASAN}

Produk yang dikembangkan dalam penelitian ini adalah bahan ajar IPA berbasis lingkungan untuk siswa kelas IV Sekolah Dasar.Adapun model pengembangan yang digunakan dalam penelitian ini adalah model pengembangan yang diadaptasi dari model pengembangan Borg dan Gall (1983) yang dimodifikasi menjadi 7 tahapan, yaitu: analisis kebutuhan, desain, pembuatan prototype, uji coba lapangan, revisi bahan ajar, penerapan bahan ajar dalam pembelajaran dan revisi terakhir.Adapun hasil penelitian yang telah dilakukan diSDN 3 Jenggik dengan judul "Pengembangan Bahan Ajar IPA Berbasis Lingkungan Kelas IV SDN 3 Jenggik Tahun Pelajaran 2017/2018" meliputi validasi ahli materi dan ahli tampilan, data uji coba, angket respon siswa, THB (Tes Hasil Belajar) dan kajian prodak akhir. Berikut dibahas masing-masing hasil penelitiannya.Data hasil uji coba skala kecil

Data hasil pretes dan posttes siswa disajikan dalam tabel.

Tabel 3

Hasil pretes dan posttes

\begin{tabular}{|c|l|c|c|}
\hline No. & \multicolumn{1}{|c|}{ Data } & Hasil pretes & Hasil posttes \\
\hline 1. & Nilai rata-rata & 49 & 76 \\
\hline 2. & Skor tertinggi & 70 & 90 \\
\hline 3. & Skor terendah & 30 & 60 \\
\hline 4. & Ketuntasan klasikal & 20 & 80 \\
\hline
\end{tabular}

Berdasarkan tabel hasil pretes dan posttes tersebut diperoleh nilai rata-rata pretes adalah 49 sedangkan rata-rata posttes adalah 76. Skor tertinggi pada pretes adalah 70 dan skor terendah 30, sedangkan pada postes skor tertinggi adalah 90 dan skor terendah 60.Nilai ketuntasan klasikal pretes adalah 20\%, sedangkan 
postes $80 \%$, Dengan demikian nilai antara pretes dengan posttes menunujukkan nilai yang berbeda dimana pretes rendah dan setelah pembelajaran dilakukan dengan mengunakan bahan ajar IPA berbasis lingkungan menunjukkan nilai siswa pada postes tinggi.

Data hasil pretes dan posttes

Data yang diperoleh setelah uji coba skala kecil diperoleh dari 23 orang siswa sebagai subjek uji coba terdapat 10 siswa yang tuntas dan 13 siswa tidak tuntas dengan ketuntasan klasikal 43,47\%. Setelah pembelajaran dilakukan, siswa diberikan tes untuk mengetahui ketercapaian tujuan pembelajaran.Tes hasil belajar diberikan kepada 23 siswa. Berdasarkan hasil uji coba setelah pembelajaran dilakukan, diperoleh 4 orang siswa yang tidak tuntas dan 19 orang siswa yang tuntas dengan ketuntasan klasikal 82,6. Data hasil pretes dan posttes siswa disajikan dalam tabel.

Tabel 6

Hasil pretes dan posttes

\begin{tabular}{|c|l|c|c|}
\hline No. & \multicolumn{1}{|c|}{ Data } & $\begin{array}{c}\text { Hasil } \\
\text { pretes }\end{array}$ & $\begin{array}{c}\text { Hasil } \\
\text { postes }\end{array}$ \\
\hline 1. & Nilai rata-rata & 61,52 & 75,21 \\
\hline 2. & Skor tertinggi & 90 & 100 \\
\hline 3. & Skor terendah & 40 & 50 \\
\hline 4. & Ketuntasan klasikal & 43,47 & 82,6 \\
\hline
\end{tabular}

Berdasarkan tabel hasil pretes dan posttes tersebut diperoleh nilai rata-rata pretes adalah 61,52 sedangkan rata-rata posttes adalah 72,21 . Skor tertinggi pada pretes adalah 90 dan skor terendah 40, sedangkan pada postes skor tertinggi adalah 100 dan skor terendah 50. Nilai ketuntasan klasikal pretes adalah 43,47\% sedangkan posttes82,6\%. Dengan demikian nilai antara pretes dengan posttes menunujukkan nilai yang berbeda dimana pretes rendah dan setelah pembelajaran dilakukan dengan mengunakan bahan ajar IPA berbasis lingkungan menunjukkan nilai siswa pada posttes tinggi.

Berdasarkan hasil validasi dari tim ahli dan angket respon siswa maka bahan ajar yang dikembangkan layak digunakan dalam proses pembelajaran. Validasi ahli terhadap produk yang dikembangkan adalah untuk menggali 
komentar, saran baik secara tertulis maupun secara lisan mengenai produk yang dikembangkan.Pada tahap ini dilaksanakan dengan menyerahkan produk pembelajaran yang dikembangkan untuk dievaluasi dengan instrumen penilaian materi maupun penilaian tampilan bahan ajar berbasis lingkungan.Validasi ini dimaksudkan untuk mengetahui aspek kebenaran dan kelayakan baik dari isi materi maupun tampilan dari bahan ajar yang dikembangkan. Validasi dari ahli materi dan ahli tampilan tersebut digunakan untuk mengetahui kualitas produk pembelajaran yang dikembangkan dan yang akan digunakan sebagai dasar untuk mengadakan perbaikan atau revisi agar dapat memperoleh produk yang berkualitas.

Berdasarkan hasil dari THB (Tes Hasil Belajar) siswa yang diperoleh dari uji coba skala kecil bahwa bahan ajar yang dikembangkan dapat digunakan selanjutnya pada uji coba lapangan atau uji coba skala besar tampa harus di validasi lagi oleh tim validator. Karena hasil dari THB (Tes Hasil Belajar) siswa dilihat darinilai rata-rata siswa mencapai 85,86 denganketuntasan klasikal yaitu 91,3\%.Menunjukan bahwa bahan ajar dapat digunakan untuk meningkatkan hasil belajar siswa. Hal ini disebabkan oleh beberapa faktor lain yaitu faktor motivasi belajar siswa, minat siswa, perhatian siswa, dan suasana belajar yang yang aktif karena menggunakan bahan ajar berbasis lingkungan.

Kemudian dari hasil respon siswa yaitu dari 23 jumlah siswa secara keseluruhan, dengan rata-rata $83,12 \%$. Dengan demikian, bahan ajar berbasis lingkungan dapat digunakan dalam proses pembelajaran di sekolah dasar pada pelajaran IPA untuk dapat meningkatkan hasil belajar siswa. Karena bahan ajar yang dikembangkan adalah suatu bahan ajar yang dimana sistem belajar lebih menekankan pada bagaimana siswa membangun konsep-konsep yang ada pada diri siswa melalui pengamatan dan percobaan yang dilakukan oleh siswa dan selanjutnya mereka dapat mengimplentasikan konsep yang meraka terima dalam kehidupan sehari-hari. 


\section{KESIMPULAN}

Berdasarkan hasil penelitian pengembangan bahan ajar IPA berbasis lingkungan pada Standar Kompetensi memahami hubungan antara struktur bagian tumbuhan dengan fungsinya di kelas IV SDN 3 Jenggikdapat diambil kesimpulan sebagai berikut :

1. Telah dihasilkan bahan ajar IPA berbasis lingkunganpada materi pokok bagianbagian tumbuhan dan fungsingya. Proses pengembangan bahan ajar mengacu pada model pengembaganBorg and Galldengan tahap analisis kebutuhan, desain, pembuatan prototype bahan ajar, uji coba lapangan, revisi bahan ajar, penerapan bahan ajar, revisi terakhir.

2. Bahan ajar IPA berbasis lingkungan pada pokok bahasan bagian-bagian tumbuhan dan fungsinya yang dikembangkan peneliti ini telah dinilai valid oleh tim validator dengan nilai kevalidan bahan ajar dari aspek materi sebesar 3,23 nilai kevalidan dari aspek media sebesar 3,3. Sehingga keseluruhan komponen bahan ajar dinyatakan valid. Respon siswa dengan menggunakan bahan ajar berbasis lingkungan berkategori "tinggi" dengan rata-rata 83,12, sehingga dapat dikatakan siswa memberikan respon yang positif terhadap bahan ajar yang dikembangkan.

3. Dari data hasil uji coba sekala besar diperoleh nilai rata-rata siswa mencapai 85,86 dengan ketuntasan klasikal 91,3\%, sehingga sudah melebihi KKM yang sudah ditentukan yakni 6,25. Dan secara klasikal nilai keseluruhan siswa mencapai 91,3\% sehingga dapat dikatakan tuntas belajar. Berdasarkan analisis uji $\mathrm{t}$ yang dilakukan peneliti untuk melihat pengaruh bahan ajar yang dikembangkan didapatkan hasil $\mathrm{t}_{\text {hitung }}$ lebih besar dari $\mathrm{t}_{\text {tabel }}$ sehingga bahan ajar yang dikembangkan peneliti mempunyai pengaruh yang positif terhadap hasil belajar siswa. 


\section{DAFTAR PUSTAKA}

Ahmadi, dan Supatmo A, Ilmu Alamiah Dasar. Jakarta: PT. Rineka Cipta.2008

Aly, dan Rahma, Ilmu Alamiah Dasar. Jakarta: PT. Bumi Aksara.2009

Asrori, Psikologi Pembelajaran. Bandung: CV Wacana Prima.2009

Hamzah B. uno, dan Mohamad, Belajar Dengan Pendekatan Pailkem.Jakarta: Bumi Aksara.2012

Haryai, Model dan Teknik Penilaian Tingkat Satuan Pendidikan. Jakarta: Gaung Persada Press.2010

Majid, Perrencanaan Pembelajaran Mengembangkan Standar Kompetensi Guru. Bandung: PT. Remaja Rosdakarya. 2007

Mulyatiningsih, Metode Penelitian Terpan Bidang Pendidikan. Yogyakarta: CV Alfabeta.2012

Mardapi, Teknik Penyusunan Instrumen Tes dan Nontes. Jogjakarta: Mitra Cendikia.2008

Nasution, Materi Pokok Pendidikan IPA di SD. Jakarta: Universitas Terbuka. 2006

Putra, Desain Belajar Mengajar Kreatif Berbasis Sains. Jogjakarta: Diva Press. 2013

Prastowo, Panduan Kreatif Membuat Bahan Ajar Inovatif. Jogjakarta: DIVA Press.2013

Rohani, Pengelolaan Pengajaran.Jakarta: Kencana Prenada Media Group2010.

Sudjana, Penilaian Hasil Proses Belajar Mengajar. Bandung: PT. Remaja Rosdakarya.2011

Sudirman, 2011.Pengembangan Bahan Ajar Ipa Terapan Berbasis Keterampilan Generik Dan Proses Sains Di Program Studi Pendidikan Guru Sekolah Dasar (PGSD) Fkip Universitas Sriwijaya. Diunduh pada tanggal 17 Maret 